Water and Environment Journal, June 2011, Volume 25, Issue 2, pages 282-289

A geospatial approach to assessing microbiological water quality risks associated with irrigation abstraction

Knox, J.W. BSc MSc PhD *

Tyrrel, S.F. $\quad$ BSc MPhil PhD FCIWEM

Daccache, A. BSc PhD

Weatherhead, E.K. BA MA (Oxon) PhD FCIWEM

Cranfield University

Centre for Water Science

Department of Sustainable Systems

Bedfordshire MK43 OAL

$U K$

Tel 01234758365

* Corresponding author j.knox@ cranfield.ac.uk

No of words: 4710 


\title{
A geospatial approach to assessing microbiological water quality risks associated with irrigation abstraction
}

Knox, J.W.*, Tyrrel, S.F., Daccache, A., and Weatherhead, E.K.

Cranfield University, Department of Sustainable Systems, Bedfordshire, MK43 OAL, UK

* Corresponding author j.knox@ cranfield.ac.uk

\begin{abstract}
All crops that are eaten raw can present a microbiological risk to consumers. Disease outbreaks in the UK and US have illustrated that ready-to-eat crops can be a vehicle for the transmission of gastrointestinal disease. Irrigation water has been implicated as a possible source of microbiological contaminants. Over two thirds of irrigation water applied to UK salad crops is abstracted from rivers and streams. Many of these are subject to a continuous input of faecal contamination from sewage treatment works as well as intermittent inputs from livestock and sewer overflows. In this paper we show how geospatial techniques can help to assess the relationships between treated effluent discharges and abstractions and thus provide a new insight into local scale assessments of irrigation water quality. The extent to which the approach can inform risk assessments and decision-making at the farm scale is demonstrated using a case study catchment in eastern England.
\end{abstract}

Keywords: abstraction; catchment; GIS; risk assessment; salads; sewage.

\section{Introduction}

In England, consumer demands are changing, with a shift towards foods that are more healthy, quick and convenient to prepare. One sector that has grown rapidly in recent years is preprepared bagged salads. Between 2005 and 2007, national retail sales of mixed and single leaf bagged salads increased by $9 \%$, with market research showing a strong underlying growth in consumer demand (Mintel, 2009). This demand for salads and other so-called ready to eat 
(RTE) crops such as salad onions, radishes, spinach, and culinary herbs has had a major impact on the horticultural industry and particularly on water abstraction. For all these crops irrigation is an essential component of production and a high value use of water (irrigation benefits per unit applied, $£ / \mathrm{m}^{3}$ ), helping to maximise quality in terms of colour, size, shape, skin finish and taste (Knox et al., 2000). But the reliance on irrigation water brings with it the potential to be a source of contaminants. As salads are not cooked prior to eating it is critical that production practices ensure that the potential for contamination with hazards to public health, such as infectious microorganisms, is reduced to a tolerable level. Both horticultural growers and retailers are concerned regarding the potential food safety risks associated with using water of low microbiological quality on crops that are not processed prior to human consumption. A study for the Food Standards Agency (FSA) concluded that although water used in agriculture in the UK may be a contributory factor in some food-poisoning incidents, it is not possible to quantify the extent of the problem (Groves et al., 2002). However, epidemiological and risk-assessment studies elsewhere have indicated the existence of risks associated with the consumption of salads that have been irrigated with poor quality water (Shuval et al., 1997; Blumenthal et al., 2000; Hamilton et al., 2000; Petterson et al., 2001; Stine et al., 2005).

In 2003, a survey of irrigation practices within the RTE crop sector was conducted as part of a UK study to assess microbiological risks associated with irrigation water quality (Tyrrel et al., 2006). That study collated information on the types of salads grown, the areas irrigated, and water sources used via a postal survey of registered horticultural holdings. It found that lettuces accounted for half the total cropped area, whilst spinach and salad onions accounted for a further third (32\%). Survey data was also used to correlate irrigation water source against area, by crop type (Table 1). This showed that surface water (rivers and streams) accounted for $70-90 \%$ of all water abstracted for irrigating lettuce, spinach, salad onions and celery in England. These industry figures are consistent with national government statistics, 
which showed that $65 \%$ of all irrigation abstractions are from surface sources with relatively little storage (Weatherhead and Knox, 2000). In general terms, river water would be expected to have the greatest faecal contamination compared to other water sources (Figure 1). This is because of the continuous discharge of sewage treatment works (STW) effluent into the watercourses and inputs from intermittent sources of faecal contamination, such as run off from livestock farms and discharges from combined sewer outfalls, associated with run off following heavy rainfall events. River water is thus the most commonly used source for irrigating salads and the source most likely to be contaminated with hazardous microorganisms. The response of salad producers to this threat needs to demonstrate due diligence and be proportionate to the risk posed. However, the industry survey in 2003 highlighted a limited and uncertain response to this microbiological hazard (Tyrrel et al., 2006). Typically, monitoring of the microbiological quality of the irrigation water was limited to annual tests on source water. The results were stored for reference or to demonstrate conformity to current grower protocol requirements but had no specific operational role. Many growers reported being unclear as to how to interpret microbiological water quality data in the absence of water quality guidelines. The development of risk assessments for irrigation abstraction points was not commonplace. Many growers referred to the lack of practical guidance to assist them in making rational decisions with regard to monitoring and managing their irrigation water quality. In response to the identified need for better guidance the Horticultural Development Council launched their "Keeping it clean" campaign in 2005 to provide generic practical advice to growers on avoiding microbial contamination in salad production.

Academics and practitioners working in the field of catchment assessment and planning will be familiar with the routine use of sophisticated catchment-scale river water quality simulation models such as SIMCAT (Crabtree et al., 2009). Whereas modelling approaches for chemical pollutants such as nutrients have been the subject of much investment and 
development over many years, Kay et al. (2009) describe modelling approaches for faecal indicator organisms (FIO) as being in their infancy. Models capable of evaluating the delivery of FIO to designated waters such as bathing or shellfish harvesting areas are needed to ensure compliance with the Water Framework Directive (Council of the European Union, 2000) and subsidiary EU legislation such as the Bathing Water Directive (Council of the European Union, 2006). Kay et al. (2007, 2009) also highlight in particular the need for tools capable of assessing the relative magnitude of inputs from continuous inputs (principally sewage) and intermittent inputs driven by rainfall events (e.g. from agriculture). The authors illustrate the application of their latest screening tool which combines water quality, hydrological and land cover data to predict FIO concentrations in river water discharging to the sea in England and Wales.

Whilst FIO modelling approaches such as those described above are essential for river basin planning in support of the implementation of the Water Framework Directive, as a tool they are inappropriate for individual abstractors confronted with the challenge of assessing irrigation water quality risks at the farm-scale. In this paper we assess the potential benefit of using data and maps to combine locally relevant geospatial information to aid this risk assessment process. The paper focuses on a catchment in eastern England where irrigated production using surface water is concentrated and where a large number of STW discharges contribute to local river flows. A description of the datasets and mapping, and discussion of the future role of geospatial techniques to support risk assessment and management of irrigation water quality at the farm level, is provided.

\section{Methodology}

In summary, the spatial distribution of irrigation abstraction points have been mapped and analysed in relation to the location of sewage treatment works (STW) discharges using a Geographical Information System (GIS, Arcview v9.2). The Environment Agency (EA) 
Anglian Region was chosen as a study area as it is experiencing major population growth and a rising demand for water, particularly for public water supply and irrigation (EA, 2008a).

Geo-referenced datasets containing information on abstractions and discharges were obtained from the EA. At a regional level, this assessment helped to identify catchments where there was a large concentration of discharge and irrigation abstraction points. A catchment was then identified and used as the basis for conducting a more detailed local scale assessment.

All abstractions from surface and groundwater for spray irrigation in England and Wales require a licence from the EA under the Water Resources Act (1991). The licensed and abstracted volumes for irrigation together with supplementary information (location, water source, peak rates) for each licence are recorded by the EA within their national abstraction licensing database (NALD). For this study, data for 2008 were used. The abstraction licensing data were processed, imported into the GIS and mapped to show the spatial distribution of irrigation abstraction licences, classified by licensed volume.

In order to protect the environment, water quality and human health, the EA are required by legislation to regulate the quality and quantity of discharges in England and Wales. All discharges, whether from sewage or trade effluent, to surface water, such as rivers, streams, canals, groundwater or the sea, require a 'consent to discharge'. Information on the licensed volumes for all discharge consents in EA Anglian Region for 2008 were obtained. This included all agricultural, waste, landfill, trade and sewage discharges. The data were screened to exclude discharge consents relating to activities other than sewage treatment works (either final or treated effluent) from water companies. As before, the data were processed, imported into the GIS, classified by licensed volume, and mapped to show the spatial distribution of STW discharges across EA Anglian Region.

The above GIS analyses were useful for identifying 'hotspots' at a regional level where irrigation abstractions and discharges are concentrated. From this, a catchment was chosen to 
conduct further analysis. The distance between an irrigation abstraction point and the nearest upstream sewage treatment works discharge point was then selected as a geospatial metric to indicate the potential risk of a specific abstraction point to poor microbiological quality. In England and Wales, the EA have defined 126 catchments as part of their Catchment Abstraction Management Strategy (CAMS) process which sets out how much water is available in each catchment and how it will be managed (EA, 2008b). Using the GIS, a comparison between surface water irrigation abstractions and STW discharges, in terms of number and licensed volume, by catchment, was completed (Table 2). From this, the Upper Ouse and Bedford Ouse catchment was selected due to its relatively small area, and high density of irrigation abstraction and STW discharge points. Each catchment is comprised of a number of water resource management units (WRMU) or sub-catchments. For this study, a WRMU was chosen which included the Flit and Ivel Rivers in Bedfordshire, where there are reported to be 180 licensed abstractions, with almost half licensed for public water supply. The other dominant use is for spray irrigation, mainly for horticultural crops (EA, 2005). In water resource terms, this WRMU is defined as having 'no water available' implying that there is no water available for further licensing at low flows although water may be available at higher flows with appropriate restrictions. It is precisely this combination of low river flows during the summer months coinciding with peak demands for spray irrigation that creates potential health risks in catchments where RTE crops are grown and irrigated.

Using the GIS, the NALD data were analysed to identify irrigation abstractions within the WRMU. The data were screened to exclude abstractions from sources other than surface water. This dataset was overlaid onto a digitised river network dataset (1:50000) for the subcatchment, part of a national hydrological dataset held by the Centre for Ecology and Hydrology (CEH). Similarly, the locations of all STW discharges were overlaid onto the river network. A map showing the location of each irrigation abstraction point and STW discharge point within the catchment along the river network was produced. 
When considering microbiological risks for irrigation abstraction, it is also important to know elevational differences so that only discharges upstream from an abstraction point are considered. The final stage involved developing a digital elevation model (DEM) for the catchment in order to estimate the elevation for each STW discharge outfall and abstraction point. The DEM was produced using a gridded (raster) dataset derived by UCL and Mimas using interferometric techniques on the ERS 1 and ERS 2 satellite data and held in the Landmap Data Archive at a grid resolution of $25 \mathrm{~m}$. Using a GIS 'distance to point' algorithm, the minimum river distance from each abstraction point to the nearest upstream STW discharge outfall was calculated.

\section{Results}

The spatial distribution of irrigation abstraction licences across EA Anglian Region is shown in Figure 2. The map highlights catchments where licensed volumetric demand is concentrated, notably in parts of Cambridgeshire, the Fens, north Lincolnshire, east Suffolk and north Norfolk. These correspond to known areas of intense horticultural production. In 2008, it was reported that there were 1173 horticultural holdings in EA Anglian Region and $40 \%$ of these were engaged in growing field-scale vegetables, including RTE crops (Knox et al., 2010). The analysis shows that there are nearly 3300 irrigation abstraction licences, with a total annual licensed volume of $123 \times 10^{6} \mathrm{~m}^{3}$ (Table 2). The difference between the number of industry registered horticultural holdings and abstraction licenses is because farms have more than one abstraction appoint to cater for rotational cropping. The analysis also shows that only a quarter $(25 \%)$ of the total licensed volume is abstracted, even in a dry year such as 2003.

The spatial distribution of STWs across Anglian Region is shown in Figure 2. As expected, there are many small discharge consents $\left(<2000 \mathrm{~m}^{3}\right.$ day $\left.^{-1}\right)$, but also a notable number of very large discharges (>20000 $\mathrm{m}^{3}$ day $\left.^{-1}\right)$ associated with major towns and conurbations in the region. Overall, the analysis shows there are approximately 14000 discharge consents, with a 
total annual licensed dry weather flow (DWF), that is the combined flow (foul water and surface water) in dry weather conditions of $608 \times 10^{6} \mathrm{~m}^{3}$ year $^{-1}$, equivalent to approximately five times the licensed volume for irrigation (Table 2).

For the Upper Ouse and Bedford Ouse catchment, the location of each irrigation abstraction point relative to STW discharges along the river network was mapped (Figure 3). The GIS analysis identified 61 irrigation abstraction points and 57 discharge consents, of which 13 were for STW effluent discharge. Of the 61 irrigation abstractions, 43 were downstream from one or more STW discharge outfalls. Finally, the proportion of irrigation abstraction points in a catchment that are within a given distance of an upstream STW in the catchment was calculated (Figure 4). From this, it was deduced that $50 \%$ of irrigation abstractions are within $4500 \mathrm{~m}$ of an upstream STW outfall, and furthermore a quarter are less than $2500 \mathrm{~m}$ from an upstream STW discharge outfall. These baseline statistics reinforce the need to develop appropriate risk assessment procedures to deal with abstractions of low quality irrigation water at the farm level.

\section{Discussion}

\section{Farm level risk assessment and management}

The analysis described in this paper uses public domain data and processes it using GIS techniques such that the outputs may be presented in a useful visual format to inform water quality assessments. Although the regulatory authority (EA) publishes interactive catchment maps on their website for use by the general public, it is not possible to obtain aggregate catchment statistics on discharges or irrigation abstractions. We suggest that from the perspective of a technical manager involved in agri-food production needing to risk assess irrigated RTE crop production, the availability of maps and data such as the examples given in Figures 3 and 4would be a useful step forward. These data could, for example, permit a preliminary, risk-based classification of abstraction points for agribusinesses operating in the 
catchment. Abstraction locations for which there is no upstream discharge point could be classified as 'low risk' and those in close proximity to discharge points would receive a higher risk classification. However, as discussed earlier, basing risk assessment classes solely on proximity to sewage discharge points would be a crude metric. By integrating additional data on river discharges into the GIS, dilution factors could be estimated and taken into account. The use of remote sensed land cover data could also highlight agricultural sources of faecal contamination, and locations of sewer overflows. Future augmentation and refinement of this methodology should not however lose sight of the needs of the user for a decisionsupport tool that is readily interpretable by an individual who is not a water quality specialist. The key is in ensuring that a sensible balance is struck between collating information at the catchment level (e.g. river discharge, land use) and providing useful data and maps that combine a variety of parameters for interpretation at the farm level (abstraction point).

Geospatial analyses such as this have the potential to complement broader water quality monitoring and risk management decision making. Current water quality monitoring by abstractors is of limited spatial and temporal resolution (Tyrrel et al., 2006). Intuitively, one might argue that increased monitoring could render a catchment assessment redundant - if monitoring is conducted more frequently, abstraction points could be classified on the basis of actual data rather than assumptions derived from geospatial information on upstream discharges and land use. However, monitoring is expensive and particularly challenging if the high magnitude in variability of FIO concentrations in rivers is to be accurately assessed (Fremaux et al., 2008). Researchers have repeatedly shown a consistent association between high flow events in UK rivers and elevated FIO concentrations (Kay et al., 2009). Rather than rely on reactive and costly monitoring, the development of a geospatial approach supports a more proactive catchment risk assessment more akin to the Water Safety Plans advocated by the World Health Organisation for managing drinking water quality from catchment to consumer (WHO, 2005). The frequency of water quality monitoring could be informed by the 
risk classification of abstraction points - higher risk sites should be monitored more frequently whereas baseline monitoring may be acceptable for less risky sites. Monitoring data would help to validate the risk-based classification generated by the GIS.

Once abstraction points have been classified on a risk-based scale, appropriate risk management decisions may then be considered. Options worthy of consideration include the matching of non-salad crops with more risky abstraction points; switching technologies from overhead to micro (drip) irrigation to help reduce/eliminate contact between the irrigation water and the crop surfaces; the prescription of minimum defined intervals between irrigation with low quality water and crop harvest, and investment in water storage and water treatment technologies.

\section{Methodological limitations}

The approach outlined in this scoping study has a number of limitations which must be recognised. The EA NALD dataset provides information on the location of individual licensed abstractions for irrigation. However, even in a dry year, less than a third of all water licensed for irrigation in England is actually abstracted, for a variety of reasons. For example, in some catchments the water may not be available for abstraction when needed due to low river flows or low aquifer levels. The nature of rotational cropping also means that in each year the location of abstraction points vis a viz the fields being irrigated may not be suitable. Further work is thus required to refine the mapping of abstraction points, to consider only those that are actually used each year.

Improved knowledge of the field locations where RTE crops are grown is also needed. The current approach ignores the composition of land use in the catchment and hence it is difficult to screen those abstraction points which are in close proximity to STW discharge outfalls ('high risk') and being used for irrigating RTE crops. This could be undertaken using high 
resolution remote sensing imagery to generate maps showing the spatial distribution of RTE crops at both farm and catchment levels.

Information on the rates and timing of abstraction would also be needed for each abstraction point. Depending on flow characteristics, abstractors are required to record peak rates (usually daily, but sometimes hourly or absolute) to comply with licence conditions. Coupling this with data on the timings of abstraction would help to identify how peak rates of water abstraction compare against river flows and likely FIO concentrations.

The assumption that proximity to an upstream discharge inevitably leads to abstracted water being of low quality is too simplistic. It is known that pathogens such as Escherichia coli O157:H7 have the ability to survive in river water for weeks which suggests that viable cells may travel significant distances from the point of discharge (Avery et al., 2008). However, the outputs presented in this paper need to be used as an indicator of potential risk and interpreted intelligently. The water discharged from a sewage treatment works is not necessarily of poor microbiological quality. The technologies employed by sewage treatment operators vary and some are more efficient in pathogen removal than others. Furthermore, the concentrations of pathogens reaching a downstream abstraction point are influenced by factors such as ambient weather conditions, dilution, natural die-off, and time of travel. None of these processes are currently considered in the current geospatial approach, but some could be usefully integrated, notwithstanding the need to maintain ease of use.

Finally, there is the issue regarding visual representation of complex data. The sophisticated graphics and visualisation capabilities of modern GIS software can generate highly convincing outputs, whilst concealing spatial modelling and interpretation errors (Knox et al., 1999). Map outputs can of course be extremely useful, particularly for identifying water related issues that have temporal and spatial dimensions, but care must be taken to ensure that 
the GIS capability is used to reveal what is known rather than conceal the assumptions and uncertainty underlying a coloured map.

\section{Conclusions}

This scoping study considers the key issues in developing a simple yet robust framework in support of risk assessing the microbiological quality of water for irrigation abstraction at the farm level. At present there is a noticeable gap between what is currently undertaken at the catchment scale to understand the dynamics of land and water management on the microbiological quality of water resources and its various uses downstream, and the specific requirements for individual abstractors concerned with the quality of their water abstractions. The study demonstrates how it is possible to combine datasets using a geospatial approach to assess the relative risks of faecal contamination at different abstraction locations, although further information on land use, stream flows, and actual discharge are needed to provide a more detailed picture.

\section{Acknowledgement}

We acknowledge the Environment Agency (Anglian Region) for provision of spray irrigation licensed abstraction and sewage treatment discharge data.

\section{References}

Avery, L.M., Williams, A.P., Killham, K., and Jones, D.L. (2008). Survival of Escherichia coli $\mathrm{O} 157: \mathrm{H7}$ in waters from lakes, rivers, puddles and animal-drinking troughs. Science of the Total Environment 389: 378-385.

Blumenthal, U. J., Mara, D.D., Peasey, A., Ruiz-Palacios, G., and Stott, R. (2000). Guidelines for the microbiological quality of treated wastewater used in agriculture: recommendations for revising WHO standards. Bull. WHO 78, 1104-1116. 
Council of the European Union (2000), Directive 2000/60/EC of the European Parliament and of the Council of 23 October 2000 establishing a framework for Community action in the field of water policy. Official Journal of European Union, L327, 1-72.

Council of the European Union (2006). Directive 2006/7/EC of the European Parliament and of the Council of 15 February 2006 concerning the management of bathing water quality and repealing Directive 76/160/EEC. Official Journal of European Union, L64, 37-51.

Crabtree, B., Kelly, S., Green, H., Squibbs, G., and Mitchell, G. (2009). Water Framework Directive catchment planning: a case study apportioning loads and assessing environmental benefits of programme of measures. Water Science and Technology, 59, 407-416.

Environment Agency (2005). The Upper Ouse and Bedford Ouse Catchment Abstraction Management Strategy. March 20905. Environment Agency. Exeter, 50pp.

Environment Agency (2008). Water resources in England and Wales - current state and future pressures. Environment Agency. Bristol, 23pp.

Environment Agency (2008). Managing water abstraction - interim update June 2008. Environment Agency. Bristol, 24pp.

Fremaux, B., Boa, T., Chaylowski, A., Kasichayanula, S., Gritzfeld, J., Braul, L., and Yost, C. (2008). Assessment of the microbial quality of irrigation water in a prairie watershed. Journal of Applied Microbiology, 106, 442-454.

Groves, S. J., Davies, N., and Aitken, M.N. (2002). A review of the use of water in UK agriculture and the potential risks to food safety. Report B17001. Food Standards Agency, London.

Hamilton, A.J., Stagnitti, F., Premier, R., Boland, A., and Hale, G. (2000). Quantitative Microbial Risk Assessment Models for Consumption of Raw Vegetables Irrigated with Reclaimed Water Applied and Environmental Microbiology, 72, 3284-3290. 
Kay, D., Anthony, S., Crowther, J., Chambers, B.J., Nicholson, F.A., Chadwick, D., Stapleton, C.M., and Wyer, M.D. (2009). Microbial water pollution: A screening tool for initial catchment-scale assessment and source apportionment. Science of the Total Environment (in press).

Kay, D., Edwards, A.C., Ferrier, R.C., Francis, C., Kay, C., Rushby, L., Watkins, J., McDonald, A.T., Crowther, J. and Wilkinson, J. (2007). Catchment microbial dynamics: the emergence of a research agenda. Progress in Physical Geography, 31, 59-76.

Knox, J.W., and Weatherhead, E.K. (1999). The application of GIS to irrigation water resource management in England and Wales. Geographical Journal 165, 90-98.

Knox, J.W., Morris J, Weatherhead, E.K. and Turner A.P. (2000). Mapping the financial benefits of sprinkler irrigation and potential financial impact of restrictions on abstraction: a case study in Anglian Region. Journal of Environmental Management 58, 45-59.

Knox, J.W., Kay, Rodriguez-Diaz, J.A., Weatherhead, E.K. and Kay, M.G. (2010) Development of a water strategy for horticulture in England and Wales. Journal of Horticultural Science and Biotechnology 85(2): 89-93.

Mintel (2009) Markey survey report for fresh produce (bagged salads). http://academic.mintel.com/sinatra/oxygen_academic/search_results/show\&/display/id=22017 5/displaytables/id=220175

Petterson, S.R., Ashbolt, N.J., and Sharma, A. (2001). Microbial risks from wastewater irrigation of salad crops: a screening-level risk assessment. Water Environment Research 73, $667-672$.

Stine, S. W., I. Song, C. Y. Choi, and C. P. Gerba. 2005. Application of microbial risk assessment to the development of standards for enteric pathogens in water used to irrigate fresh produce. Journal of Food Protection 68, 913-918. 
Shuval, H., Y. Lampert, and B. Fattal. (1997). Development of a risk assessment approach for evaluating wastewater reuse standards for agriculture. Water Science and Technology 35, 1520.

Tyrrel, S.F., Knox, J.W., and Weatherhead, E.K. (2006). The microbiological quality of water used to irrigate salad crops: an assessment of the options available. Journal of Food Protection 69, 2029-2035.

Weatherhead, E.K. and Knox, J.W. (2000). Predicting and mapping the future demand for irrigation water in England and Wales. Agricultural Water Management, 43, 203-218. WHO (2005). Water safety plans: Managing drinking-water quality from catchment to consumer. World Health Organisation. Geneva. 
Figure 1 Indicative range in irrigation water quality for different types of water source.

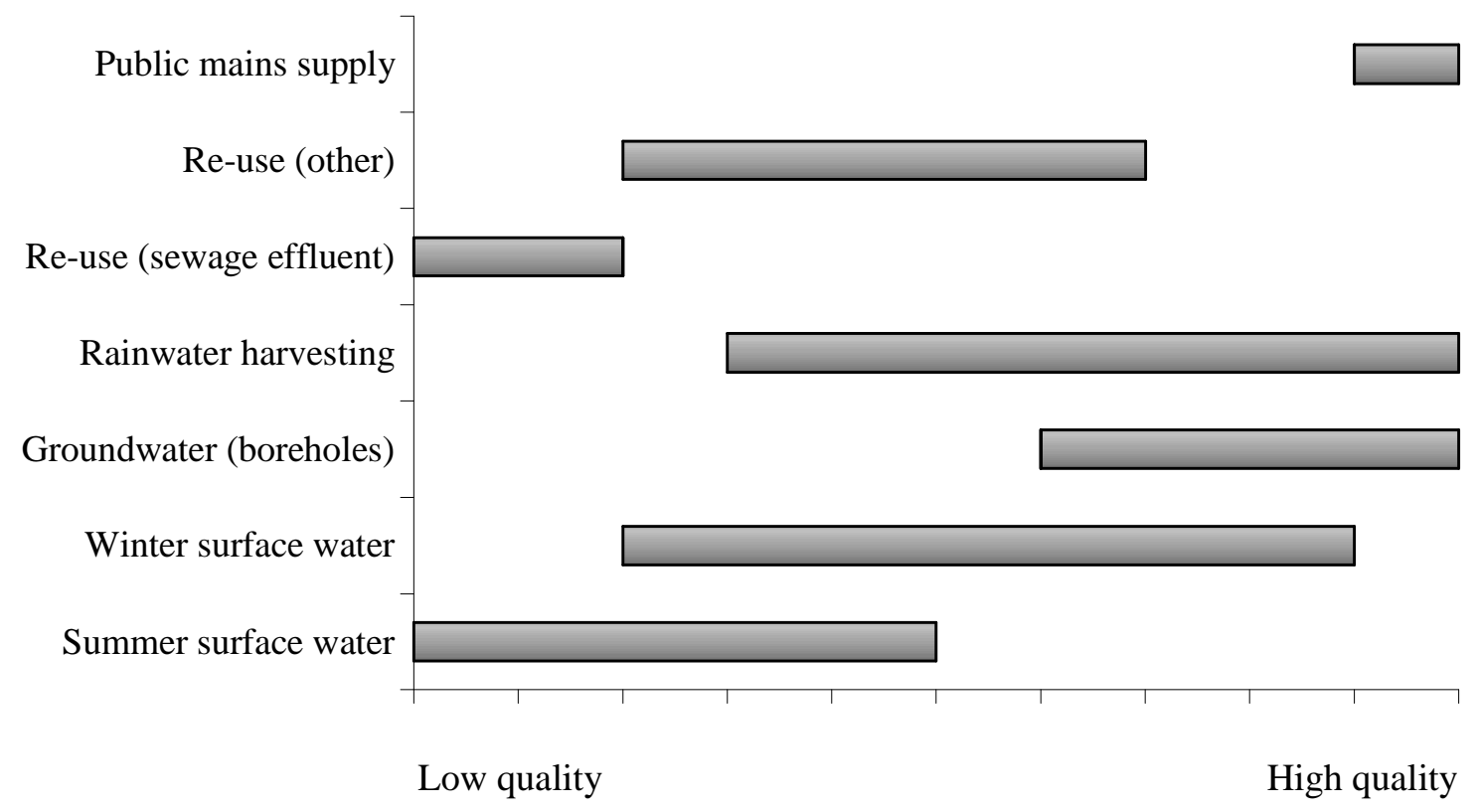


Figure 2 Spatial distribution of STW discharge points and licensed volumes ( $\mathrm{m}^{3} /$ day), and location of abstraction points for agricultural and horticultural irrigation and licensed volumes $\left(\mathrm{m}^{3} \mathrm{yr}^{-1}\right)$ in EA Anglian Region, in 2008.
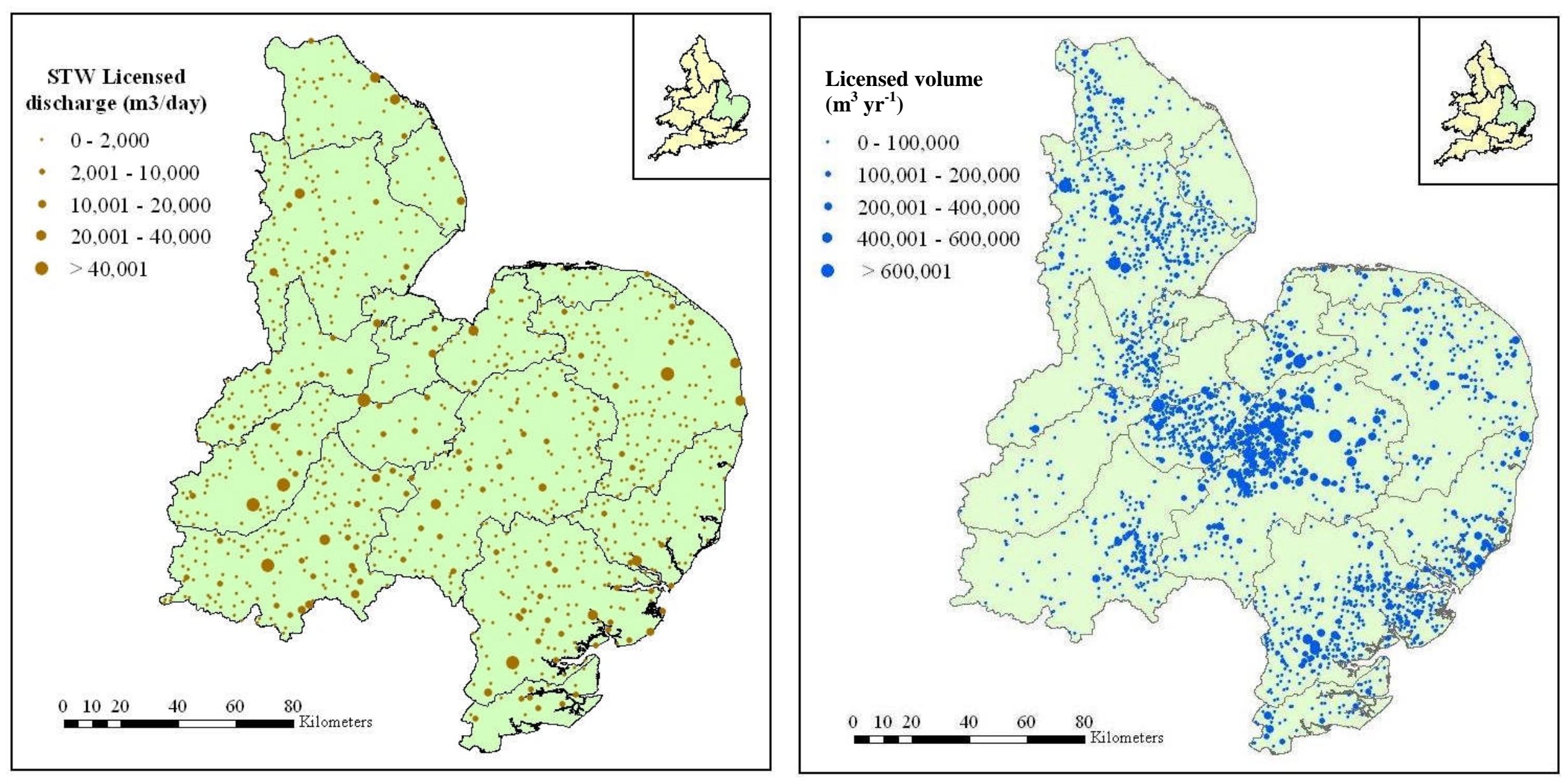
Figure 3 Spatial distribution of irrigation abstraction points and STW discharge points in the Upper Ouse and Bedford Ouse sub-catchment in EA Anglian Region, in 2008.

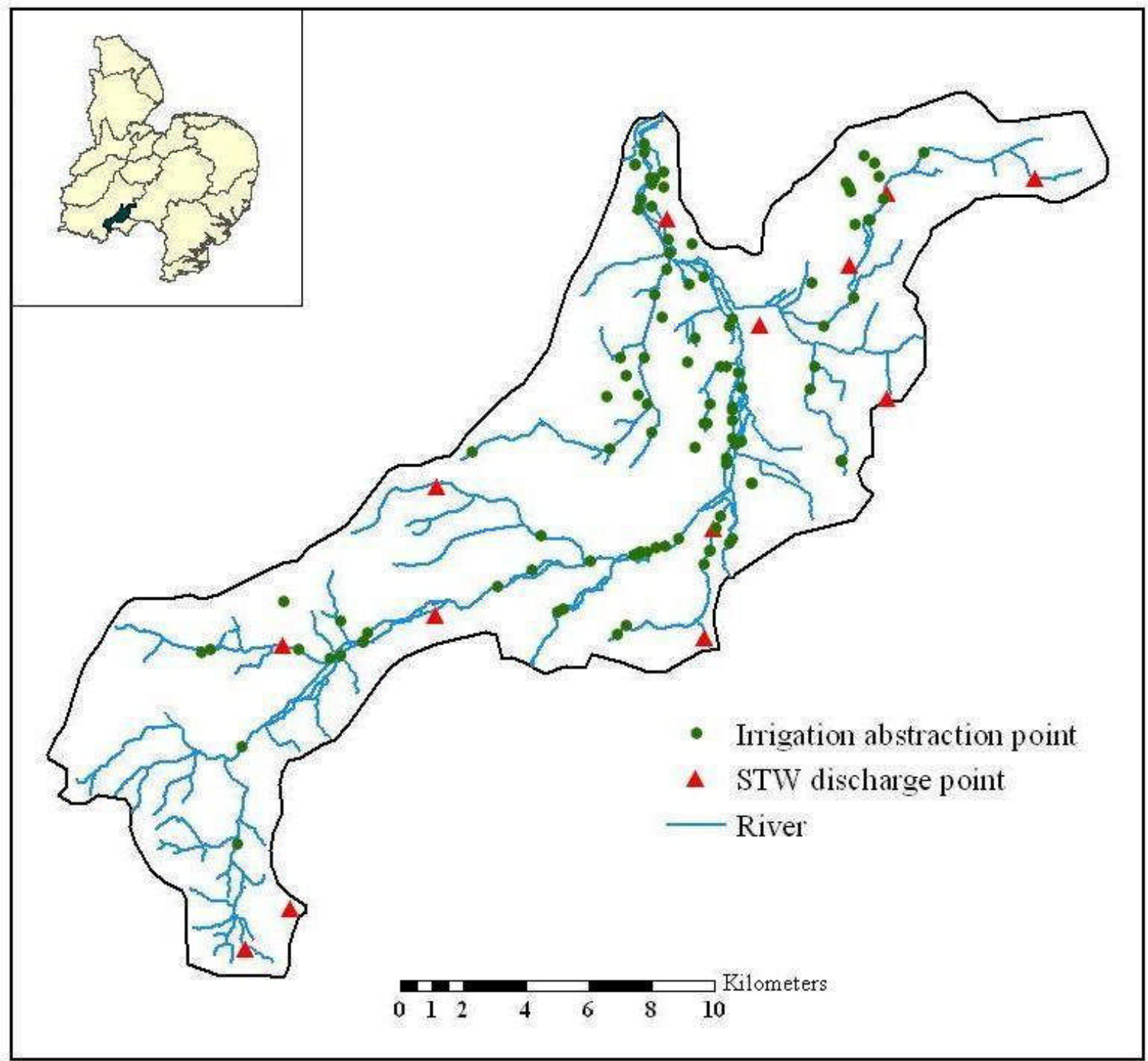


Figure 4 Minimum upstream distance (m) from each irrigation abstraction point to the nearest STW discharge in the Upper Ouse and Bedford Ouse sub-catchment in 2008.

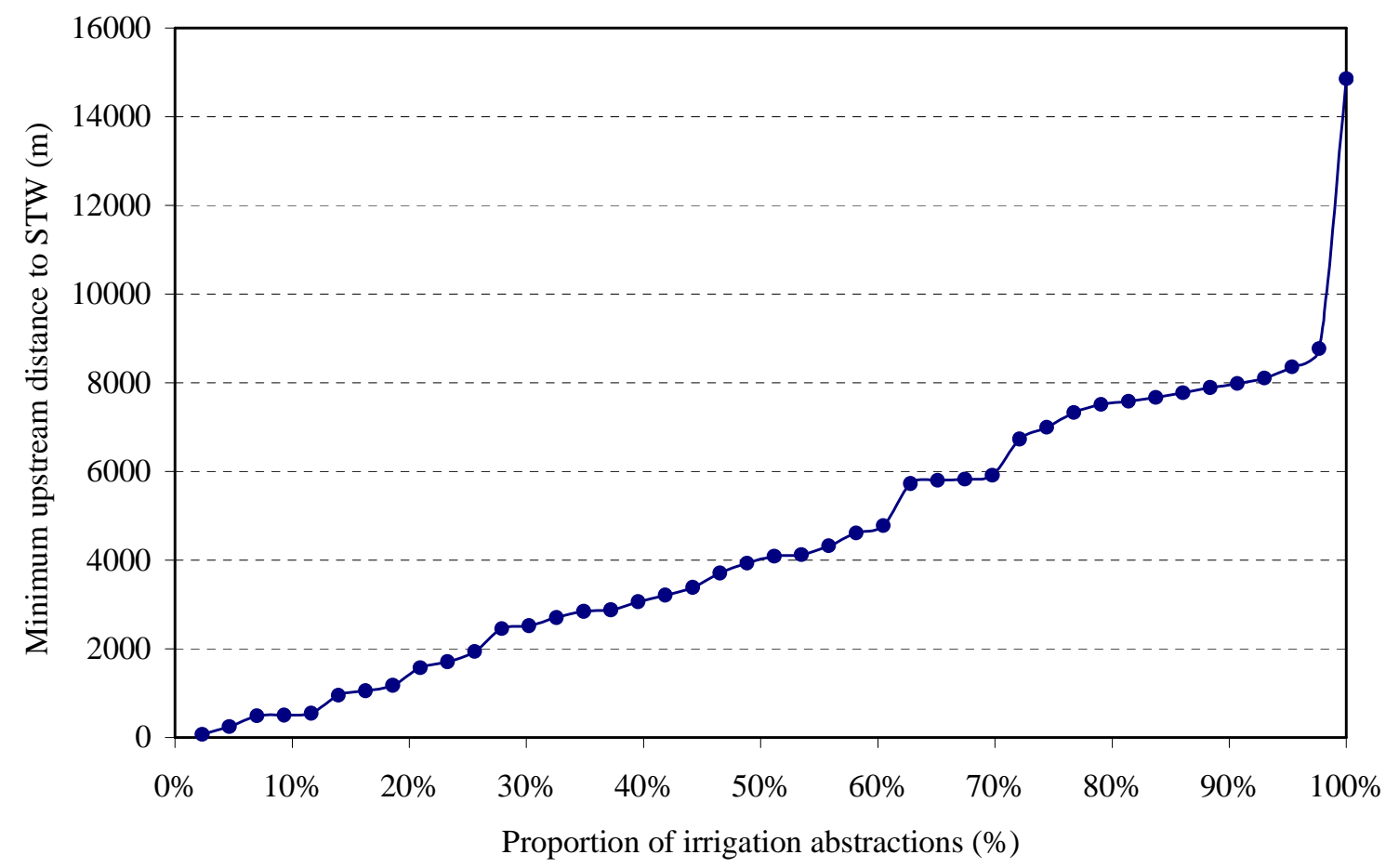


Table 1 Estimated split (\%) between water source and irrigated area, by RTE crop type.

\begin{tabular}{lrrrrrr}
\hline \multirow{2}{*}{$\begin{array}{l}\text { RTE crop } \\
\text { type }\end{array}$} & \multicolumn{2}{c}{ Ground water } & & Water source \\
\cline { 2 - 7 } & Surface water & Other \\
\hline $\begin{array}{l}\text { Type of } \\
\text { abstraction }\end{array}$ & Direct & Indirect & Direct & Indirect & $\begin{array}{r}\text { Public } \\
\text { mains }\end{array}$ & $\begin{array}{r}\text { Rainwater } \\
\text { harvesting }\end{array}$ \\
\hline Lettuce & 46 & 33 & 8 & 8 & 5 & 1 \\
Spinach & 7 & 63 & 22 & 8 & 0 & 0 \\
Onion (salad) & 90 & 3 & 6 & 0 & 1 & 0 \\
Other BLS & 4 & 9 & 67 & 16 & 4 & 0 \\
Celery & 76 & 5 & 9 & 0 & 10 & 0 \\
Culinary herbs & 22 & 19 & 39 & 10 & 7 & 3 \\
Endive & 26 & 0 & 13 & 0 & 61 & 0 \\
Rocket & 2 & 0 & 50 & 45 & 3 & 0 \\
Chinese leaf & 0 & 19 & 0 & 38 & 25 & 19 \\
Watercress & 0 & 0 & 100 & 0 & 0 & 0 \\
\hline Note: indiryyyyyyyy
\end{tabular}

Note: indirect means via reservoir. 
Table 2 Estimated number of licences, licensed and abstracted volumes for irrigation and STW discharge, by CAMS catchment in EA Anglian Region in 2008.

\begin{tabular}{|c|c|c|c|c|c|}
\hline EA CAMS catchment & $\begin{array}{r}\text { Number of } \\
\text { STW discharge } \\
\text { licences }\end{array}$ & $\begin{array}{r}\text { Total licensed STW } \\
\text { DWF discharge } \\
\left(\mathrm{Mm}^{3} \mathrm{yr}^{-1}\right)\end{array}$ & $\begin{array}{r}\text { Number irrigation } \\
\text { abstraction licenses }\end{array}$ & $\begin{array}{r}\text { Total irrigation } \\
\text { licensed volume } \\
\left(\mathrm{Mm}^{3} \mathrm{yr}^{-1}\right)\end{array}$ & $\begin{array}{r}\text { Total irrigation } \\
\text { abstracted volume } \\
2003\left(\mathrm{Mm}^{3} \mathrm{yr}^{-1}\right)\end{array}$ \\
\hline Broadland Rivers & 3060 & 91 & 226 & 8.3 & 1.8 \\
\hline Cam and Ely Ouse & 1340 & 52 & 689 & 37.0 & 10.1 \\
\hline East Suffolk & 1849 & 29 & 146 & 8.0 & 3.2 \\
\hline Louth, Grimsby Ancholme & 422 & 39 & 191 & 5.3 & 1.0 \\
\hline Nene & 809 & 79 & 98 & 2.7 & 0.5 \\
\hline North Essex & 2901 & 84 & 490 & 16.4 & 2.9 \\
\hline North Norfolk & 136 & 5 & 26 & 1.4 & 0.4 \\
\hline North West Norfolk & 277 & 13 & 90 & 5.5 & 0.9 \\
\hline Old Bedford & 240 & 9 & 459 & 14.2 & 4.5 \\
\hline South Essex & 374 & 15 & 54 & 2.3 & 0.3 \\
\hline Upper and Bedford Ouse & 1198 & 132 & 241 & 4.2 & 0.9 \\
\hline Welland & 489 & 20 & 132 & 3.7 & 0.6 \\
\hline Witham & 888 & 40 & 445 & 13.7 & 2.8 \\
\hline Total & 13983 & 608 & 3287 & 122.7 & 30.0 \\
\hline
\end{tabular}

Note: DWF, dry weather flow 
